\title{
Health care for inmates in Maputo: is it feasible to evaluate?
}

\author{
A atenção à saúde dos reclusos em Maputo: é viável avaliar?
}

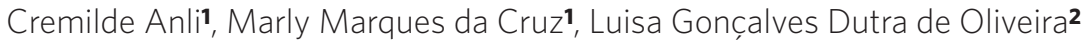

DOI: 10.1590/0103-1104202012710I

\begin{abstract}
The objective of this study was to carry out an evaluability study on the health care of inmates at the Provincial Correctional Facility in Maputo (EPPM) - Mozambique, also as from the description of health care structure and processes at EPPM, as from the description of the external and organizational contexts that interfere in health care. It is a single case study of a qualitative approach that applies the techniques of document analysis, direct observation and questionnaire. It was found that EPPM offers a precarious structure, lack of inputs and insufficient number of health care professionals. Inmates trained as peer educators or as 'chiefs of health care' give support to the activities of the medical facility propitiating their empowerment within the Correctional Facility (EP). The inmate health care in Mozambique is not an object of debate and is not addressed in the policies of the National Health Service, resulting in inadequate and insufficient care. The study affirms the importance and feasibility of future research to evaluate prison health care in Mozambique so that the implementation of actions can be based on evidence.
\end{abstract}

KEYWORDS Health evaluation. Prisons. Public policy. Health services.

RESUMO O objetivo foi realizar um estudo de avaliabilidade da atenção à saúde dos reclusos no Estabelecimento Penitenciário Provincial de Maputo (EPPM) - Moçambique com base na descrição da estrutura e dos processos de atenção à saúde no EPPM e na descrição dos contextos externos e organizacionais que interferem na atenção à saúde. Estudo de caso único com abordagem qualitativa usando as técnicas de análise documental, observação direta e questionário. Verificou-se que o EPPM possui estrutura precária, falta de insumos e profissionais em número insuficiente para a assistência à saúde. Reclusos formados como educadores de pares e ou como chefes de saúde dão apoio às atividades do posto médico, gerando seu empoderamento no Estabelecimento Penitenciário (EP). A atenção à saúde do recluso em Moçambique não é objeto de debate e não está incluída nas políticas do Serviço Nacional de Saúde, o que resulta em atenção inadequada e insuficiente. O estudo sugere a importância e viabilidade de futuras pesquisas de avaliação da atenção à saúde prisional em Moçambique para que a implantação das ações seja baseada em evidências.

PALAVRAS-ChaVE Avaliação em saúde. Prisões. Política pública. Serviços de saúde.

1 Fundação Oswaldo Cruz

(Fiocruz), Escola de Saúde

Pública Sergio Arouca

(Ensp) - Rio de Janeiro

(RJ), Brasil.

marlycruz12@gmail.com

2 Universidade Federal

Fluminense (UFF), Instituto de Saúde Coletiva (ISC) -

Niterói (RJ), Brasil.

saúde. Prisoes. Política pública. Serviços de saúde. 


\section{Introduction}

The inmate population of the world demands more health care than the general population, although its implementation in prisons remains a major challenge. Despite the conjecture strongly addressed to safety issues, medical care for that population is set aside. In Africa, where countries own few resources and where access to health care is not granted to the majority of the population, governments dislike to propose special treatment for inmates, most of which come from disadvantaged communities without access to basic health care'.

The population deprived of freedom has grown in several countries, such as the USA', with 2,100,000 inmates, China' with 1,600,000 and Brazil', with an inmate population of 690,000, or three times the existing vacancies, resulting in a precarious inmate situation ${ }^{2}$.

Health care in the Mozambican correctional system, fundamental to ensure the adequate infrastructure, environmental and nutritional conditions for healthy coexistence, has not been ensured and developed following the needs of the inmate population. The supply of services required is very small for a population that grows exponentially since 2005 without the development and improvement of the physical and structural conditions of the country's Correctional Facilities (Estabelecimentos Penitenciários - EPs). Currently, the country hospitalization capacity is 8,498 beds, $97 \%$ of which are occupied by male and mostly young ${ }^{3}$.

Graph 1. Growth of the inmate population in Mozambique

Total number of inmates

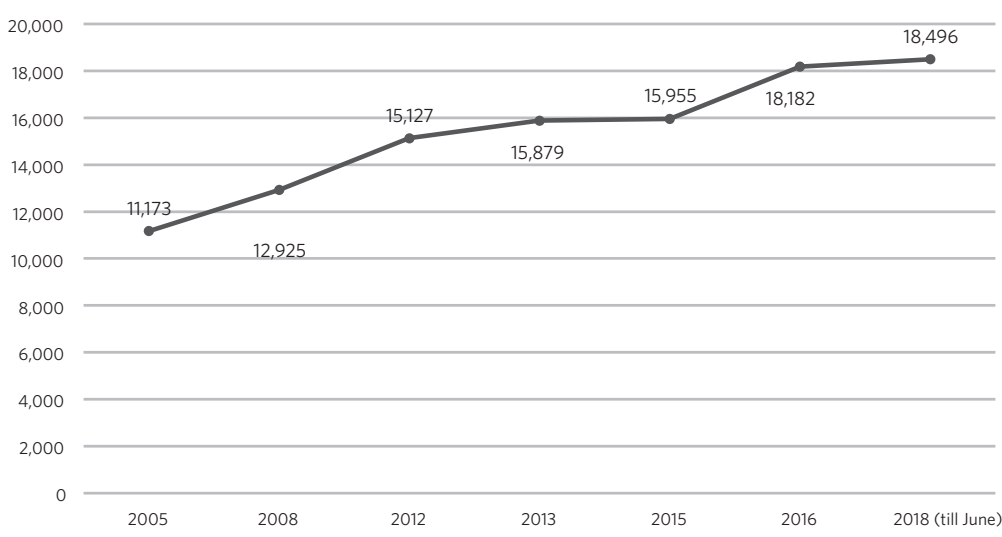

The immediate consequence of the increasing number of EP' individuals is the difficulty in classifying and separating inmates as for the crime and age, as well as in ensuring good rehabilitation. Also, overcrowding hinders the institution to provide adequate food and health services, thus increasing the incidence of diseases ${ }^{4}$. The occurrence of those situations in EPs is a sign of negligence and apparent abandonment of that population by the government. According to Kölling et al.5, carelessness in the correctional system occurs in several ways, and one of them is the lack of basic sanitation, which can provoke the onset of diseases such as cholera, malaria, parasitosis, typhoid fever and skin diseases. That growth of the criminal population requires the increase of staff in general, from prison officers to health professionals, so to meet the demand.

According to the Constitution of the Republic of Mozambique (CRM) 
[...] all citizens have the right to medical and sanitary care, by law, as well as the duty to promote and defend public health. And, the State promotes the extension of medical and sanitary care and equal access of all citizens to the enjoyment of this right6(26).

Therefore, the State should take the responsibility for diseases that the individual may acquire while serving the sentence under situations where health or preventive education activities are nonexistent ${ }^{7}$.

The Mozambican Correctional System at its provincial level is structured on Regional Correctional Facilities (3), Provincial (9), Special (4) and District (67). As per report of the National Correctional Service (Serviço Nacional Penitenciário - Sernap), the inmate health care over the country is granted in 19 health centers, which offers a part-time service on weekdays, except for a few that are full-time opened, as EPs Regional North and Center, Provincials of Cabo Delgado, Tete and Maputo. Such health units are very small in size, some provide short-term hospitalization, and are comprised of a team of three general practitioners to cover all the country ${ }^{8}$.

The United Nations Standard Minimum Rules for the Treatment of Prisoners, or Mandela Rules ${ }^{9}$, state that the provision of medical services to inmates is the responsibility of the State.

Inmates should be able to enjoy the same standards of health services available to the community and to have free access to the necessary health services, without discrimination due to their legal status ${ }^{\mathbf{9}(\mathbf{)}}$.

The Correctional System in Mozambique faces difficulties related to infrastructure, allocation of human resources able to render care services, and the existence of diseases in the midst of the inmates such as Aids and other Sexually Transmitted Infections (STIs), tuberculosis (TB), malaria, skin diseases and even nutritional problems. Among the different diseases, communicable diseases are the main health problem within the prison environment. That situation becomes a cause of special attention when those citizens benefit from being released and return to the community coexistence, generating repercussions on the social dynamics of transmission and his/her reinfection ${ }^{10}$.

Due to the continuation of reform actions and the aim of gradually improving health care, the Ministries of Justice and the Interior signed a memorandum of understanding with the Ministry of Health (Misau) in 2004 providing for the rendering of health care to inmates in correctional facilities and among different correctional facilities over the country. The parties agreed, among several themes, the following: medical and technical assistance; design of programs and implementation of projects; supply of hospital equipment and means of treatment; supply of medicines and other preventive material; support in the training of paramedic staff; rehabilitation or development of physical infrastructure as for the agreement to carry on.

Thus, the need to verify the feasibility of assessing (evaluability) the inmate health care is justified by being a susceptible and little explored theme, as well as because it is necessary to know and understand the prison health environment so to create a strategy of actions and better intervene. Moreover, the population deprived of liberty has a peculiar epidemiological situation due to the precarious conditions and the overcrowding of correctional facilities.

In this context, the aim of this article is to conduct a study on the feasibility of evaluating the health care of inmates in the Maputo Provincial Correctional Facility (Estabelecimento Penitenciário Provincial de Maputo - EPPM) - Mozambique as from the description of the structure and processes of health care in EPPM and from the description of external and organizational contexts that interfere in health care. 


\section{Methodology}

This is a single case study of qualitative approach conducted in 2016 at EPPM, located in Maputo Province, southern Mozambique.

As for Bezerra et al."11, the study on evaluation feasibility falls within the scope of the devising of an evaluation itself, consists of understandings between those involved on the object and aims the consensus on the need to carry out the evaluation. The same authors report that the study allows for the preparation of an environment favorable to future evaluations, creating opportunities for the use of results by the main stakeholders. As per Thurston and Potvin'12, this type of study allows for in-depth understandings about the object of the research and a prior assessment of the evaluation possibilities, rationalizing resources often scarce for the evaluation process.

This study on evaluation feasibility respected the following steps suggested by Thurston and Ramaliu13: (a) define the boundaries of the program and identify goals, objectives and activities; (b) identify and analyze the intervention documents to be evaluated; (c) construct the logical model, taking into account the available resources; (d) supervise the program; (e) identify the users involved in the evaluation; and (f) make recommendations on the program. The identification of these elements has also been adopted in several

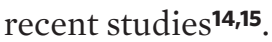

To carry out this study, the combination of the following research techniques was adopted: document analysis, direct observation and questionnaire as a way to accumulate data with credibility. Data collection was based on primary and secondary sources. Primary data were obtained by means of questionnaires and direct observation, applying semi-structured instruments. Secondary data were retrieved from the analysis of institutional documentation, national legislation, Strategic Plan of the Health Sector (Pess), ordinances, ministerial orders, laws and reports.

Picture 1 depicts the study structure on evaluation feasibility containing the techniques of data collection, documents and key informants, who, in turn, were the identified potential users.

Picture 1. Structure of the study on health care evaluability of EPPM inmates
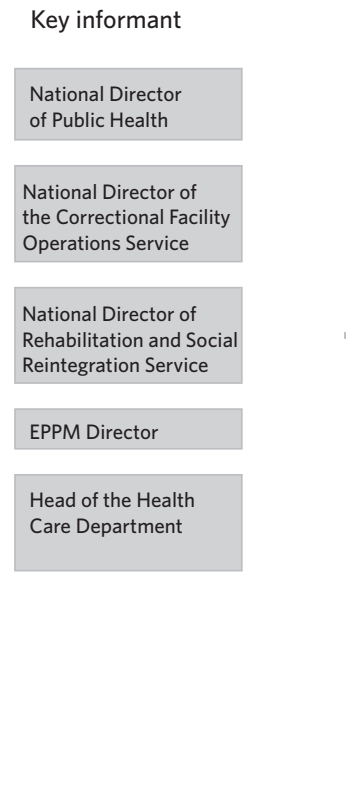

Data collection method

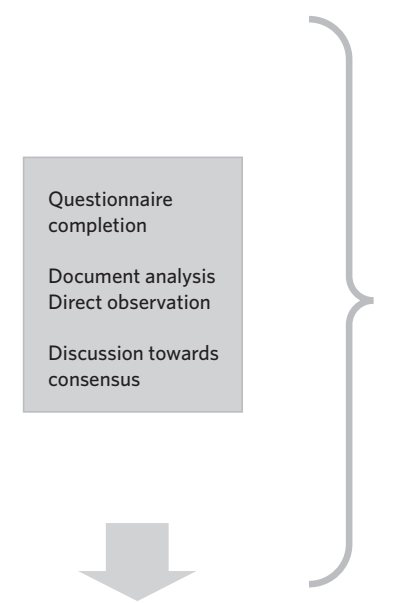

Description of Structures and Processes Logical Model Strategic analysis
Strategic plan of the health sector;

Ordinances; Ministeria

orders; Laws; Annual

reports - Misau, Sernap

and EPPM medical

facility 
Picture 1 depicts the retrieval of Decree-Law No. 26,643 of May 28, 1936; Ministerial Orders; annual reports from Misau and from the Ministry of Justice, Sernap, EPPM ; Machava General Hospital, and Health, Women and Social Action Services of Matola (Serviços de Saúde, Mulher e Ação Social da Matola - SSMAS). Initially, a superficial reading of all retrieved documents was performed; afterwards, they received an in-depth reading so to identify the points for the description of structures and processes, identification of potential users and construction of the health care logical model as for EPPM.

The direct observation of health care services allowed for data to be recorded as the facts occurred, spontaneously, without proper preparation, since the best occasion for recording is on the site where the activity is being developed. The use of that technique also consisted in observing the practices of the various Sernap employees and inmates.

A self-answering questionnaire was prepared, delivered to 28 people and answered by 21 respondents representing the National Directorate of Medical Care (Direção Nacional da Assistência Médica - DNAM), Sernap, Hospital, and Matola' SSMAS. The consent and authorization of Sernap General Directorate was previously requested and acquitted by EP, Misau and the Maputo Provincial Health Directorate. The questionnaires were delivered personally and preceded by the explanation of the research objectives and by the signing of the Informed Consent Form (Termo de Consentimento Livre Esclarecido - TCLE). The self-answering questionnaire was chosen so to avoid embarrassment, since the main researcher of the study occupied a top position in the hierarchy of the Correctional System of Mozambique.

The participants of the research were identified by the letters: PM for the two professionals assigned to the medical station; PD for the two persons in charge of EPPM directorate; CI for key informant, i.e., the five non-health professionals Managers of Misau and Sernap; and PS for the twelve health professionals at the National Health Service (SNS). The number was assigned following the storage of questionnaires. All data collected and field diary records used were analyzed by means of the content analysis technique ${ }^{\mathbf{1 7}}$ and categorized into three areas: Health Care Structure, Health Care Processes and Political-Organizational Context.

The research project was submitted to the National Committee of Health Bioethics of Mozambique and approved by means of Opinion No. 34/CNBS/2016. The study was confidential, being the participant identity kept anonymous and safe.

\section{Results and comments}

\section{Health care structure at EPPM}

The EPPM capacity is 800 inmates. It is comprised of an administrative block, a legal advisory office, a school with five classrooms, a medical station without hospitalization, a kitchen, ten pavilions including the pavilion of TB patients, a typography, a locksmith, a tailoring, a carpentry, a weaving, an external area, a place to receive family visits and the general precinct.

The medical station is located outside the administrative area, has two offices for doctor and nursing, a treatment room, an observation room, which also functions as a waiting room, the administrative wing, pharmacy, two toilets, being one for professionals and the other for inmates, a pantry and a room equipped for voluntary medical circumcision. There's no laboratory, no blood collection room nor a room for material sterilization. Besides, it lacks running water. In the clinical treatment room, there is not enough dressing materials. The conditions for HIV transmission, whose prevalence is higher in EPs, are even greater due to the lack of material. The physical structure precariousness of health units was also found in Brazil 
by Oliveira'18, who mentions the existence of medical stations without adequate ventilation, no place for the collection of blood samples and insufficient basic material resources, such as stretcher for observation.

The health team is comprised of a doctor, two general nurses, an elementary multipurpose female agent, a female worker who helps at the pharmacy and four more prison officers who provide support to the medical station. That number of employees was considered insufficient by all interviewees. The single table lists the categories and number of health professionals necessary for a better sanitary care rendering.

Table 1. Categories and number of health professionals required by EPPM, 2017

\begin{tabular}{ll}
\hline Category of required health professionals & No. of Professionals \\
\hline General physician & 2 \\
Dentist & 1 to 2 \\
Medical technician & 1 to 2 \\
Nurses & 3 to 4 \\
Social worker & 1 \\
Psychologist & 2 \\
Psychiatrist & 1 to 2 \\
\hline
\end{tabular}

Source: Prepared by the authors.

The number of professionals proposed was considered ideal for the current population of about three thousand inmates and enables 24 hour-assistance, as happens in countries such as Brazil and Spain, where assistance is provided by a fixed team comprised of a doctor, nurse, dentist-stomatologist or dentist, psychologist, social worker, and nursing assistant for a certain number of prisoners ${ }^{\mathbf{1 9}, 20}$.

The lack of quantity and quality of human resources in the health area and of medicalsurgical equipment, worsened by the limited time of assistance to ensure adequate health care result in poor provision of health care in the correctional facility. Oliveira ${ }^{18}$ arrived to the same results, revealing that health team in two correctional facilities studied was insufficient. Concurrently, Minayo and Ribeiro ${ }^{21}$ also addressed the scarcity of health professionals and the delay in providing care, mainly when the problem involves emergency care.

\section{Health care processes at EPPM}

The medical station is opened eight hours on weekdays. When it is not operational, severely ill patients are transferred to the SNS' US, while the remainders wait for the next day to receive medical care. In order to go to the medical station, inmates are accompanied by the 'health chief'. The health chief is an inmate elected by the other inmates in coordination with the direction of the correction facility whose role is to provide information from the medical station, accompany inmate patients for medical care, provide and ensure the daily taking of medicines and act as the link between inmates and the direction to easy the information flow.

The inmate admission for consultation by both the nurse and the doctor follows a specific flowchart: 
Picture 2. EPPM inmates care flow, 2017

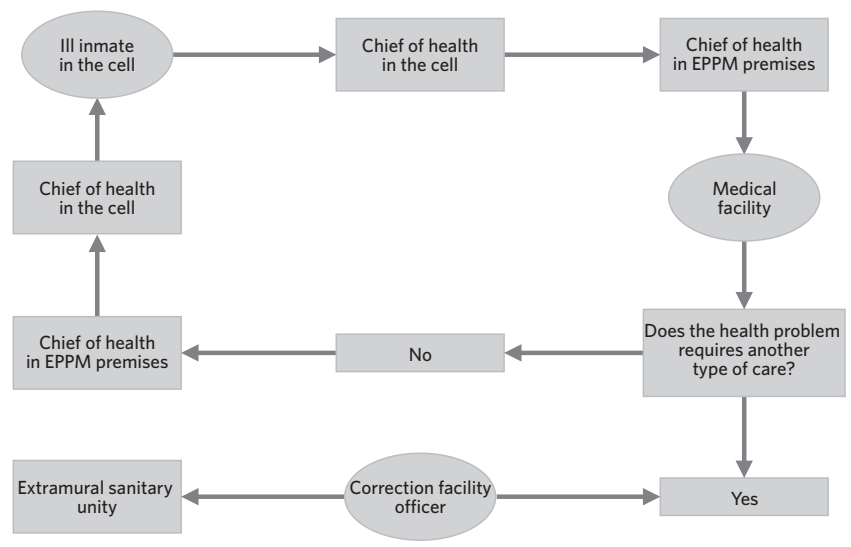

Source: Prepared by the authors.

Divergences exist between what the literature reveals and the reality in the EPPM as for the care attention flow of the sick inmate. While, for Diuana et al. $^{10}$, the prison officer plays a preponderant role, easing or hindering the action, access to health services in this study is a role attributed to an inmate, who can be chief of the cell or of the pavilion. The chief, in turn, can easy or hinder access to health services, as, in prison, the "law of the strongest' predominates, being essential that health personnel watch over the pavilions in a daily basis to identify cases that need attention.

That situation refers to Le Marcis article', which describes how the weakest patients facing the worst conditions to pay the chief of inmates are the least able to have access to medical care. That is, it is a non-institutionalized arrangement that became recognized as a formal one so to ensure the access within the correctional facility. Other authors such as Sánchez and Larouzéz2 also consider that access to health services in prison should be available to any inmate in need, but, instead, is controlled either by the prison officer or by the internal hierarchy of inmates.

As for the observed, the assistance at the medical station is provided without any privacy, and consultations are always surveilled by the health chief, who exercises his authority. That presence curbs the inmate and does not allow for him to expose his real problem. As for Coyle ${ }^{20}$, a very important aspect is the right to privacy and confidentiality during the medical consultation, and, for security reasons, the officer or any accompanying person may wait in a visible location, but outside the field of hearing.

An important fact related to care, also proven by Jólluskin et al. ${ }^{7}$, is that inmates newly arrived at EP carry infections of sexual transmission and other communicable diseases, revealing that they already arrive bearing health problems and that there is need to ensure health education actions and regular prevention measures to avoid new transmissions or reinfections. Such activities are ensured by peer educators at the medical station and in the correctional facility in general. Those educators are inmates or employees trained in the areas of health prevention and promotion, including signs and symptoms of Aids, tuberculosis, malaria, human rights, sanitation and hygiene. Most of them are health chiefs who aid the medical station in raising awareness and mobilizing other inmates as for the adoption of preventive measures ${ }^{3}$. 
Upon entering the EP, the inmate is submitted to a medical evaluation, added by the completion of an entry form that allows for a quick and early diagnosis, enabling access to timely treatment, as well as prevention measures. The health professionals interviewed consider that measure important to early identify infectious diseases for a subsequent separation of ill inmates:

[...] Screening at the entrance of inmates including permanent tracking and separation of inmates by age group. (suggested by PS10).

[...] Regular visits of doctors to inmates, screening of the inmate at the entrance to diagnose contagious infectious diseases. (by PS3).

This assessment for entry is in line with the recommendations of Mandela Rules ${ }^{9}$, which suggest the care of the persons deprived of liberty, whenever possible, before their entry into the Correctional Facility. Martins'23 also agrees with the clinical evaluation of the inmate within 24 hours after entering EP.

Additionally, health professionals who provide care in extramural health units suggest that, to improve care, it is necessary to refer or transfer inmates as soon as possible in order to avoid health aggravation or death. In this sense, respondents were unanimous on:

[...] Transfer sick inmates in time so they don't arrive terminally ill at the US. (PS4).

[...] Refer sick inmates in time they benefit from treatment, and respect US references to other hospitals that provide full care. (PS5).

The referral of sick inmates to SNS health units is frequent, although they do not always receive proper care or are discharged from the hospital without fully recovering. That lack of sensitivity and humanism and the comings and goings increasingly weaken the inmate health. The situation clearly shows a negligence in the assistance rendered to inmates, confirming the understanding of Kölling, Silva and Sá ${ }^{5}$, who claim that the inmate cannot be treated inhumanly, that being deprived of freedom does not mean losing the human condition or the right to citizenship.

Health care in EPPM is not yet fully accomplished, as can be seen from the various transfers to the stomatology service or to additional diagnostic tests ${ }^{8}$. Diarrhea, malaria, dermatitis, upper respiratory tract infections, TB, inguinal hernia and dental caries are the health problems that most trouble EPPM, being HIV and Aids, sometimes associated with TB, are the main cause of death. Another, but not least, complaint is hepatitis, although no studies reporting that disease was found in the Mozambican correctional environment.

With regard to preventive activities and health promotion, the Information, Education and Communication (IEC) materials on the prevention of TB, HIV, diarrheic diseases, etc. are exposed and posted on the walls of the medical stations, all written in Portuguese. Martins ${ }^{\mathbf{2 3}}$ mentions the low schooling or even illiteracy existing among inmates as a factor limiting the perception of messages, the reason why EPPM direction and health professionals should choose an adequate verbal communication, which will be fundamental for their understanding and change of attitude.

However, the medical station dynamics is more curative, carrying few preventive activities. Health counseling, particularly for communicable diseases such as HIV and $\mathrm{TB}$, is non-existent, despite being important to raise the inmate awareness about the existence of those diseases and their prevention methods. It is to reflect on the lack or incipience of prevention and promotion activities due to such a precarious health situation in that correctional facility, particularly as to infectious diseases.

Health professionals play an important role in health promotion, either by the distribution 
of educational material or by lectures disseminating messages. It is important to disseminate information about HIV and Aids to the entire prison population as a way to prevent transmission among that group, as well as to protect the community in general23.

Data collection and analysis resulted in the design of the Logical Model of EPPM Health Care (picture 3), enabling the description of the intervention rationality.

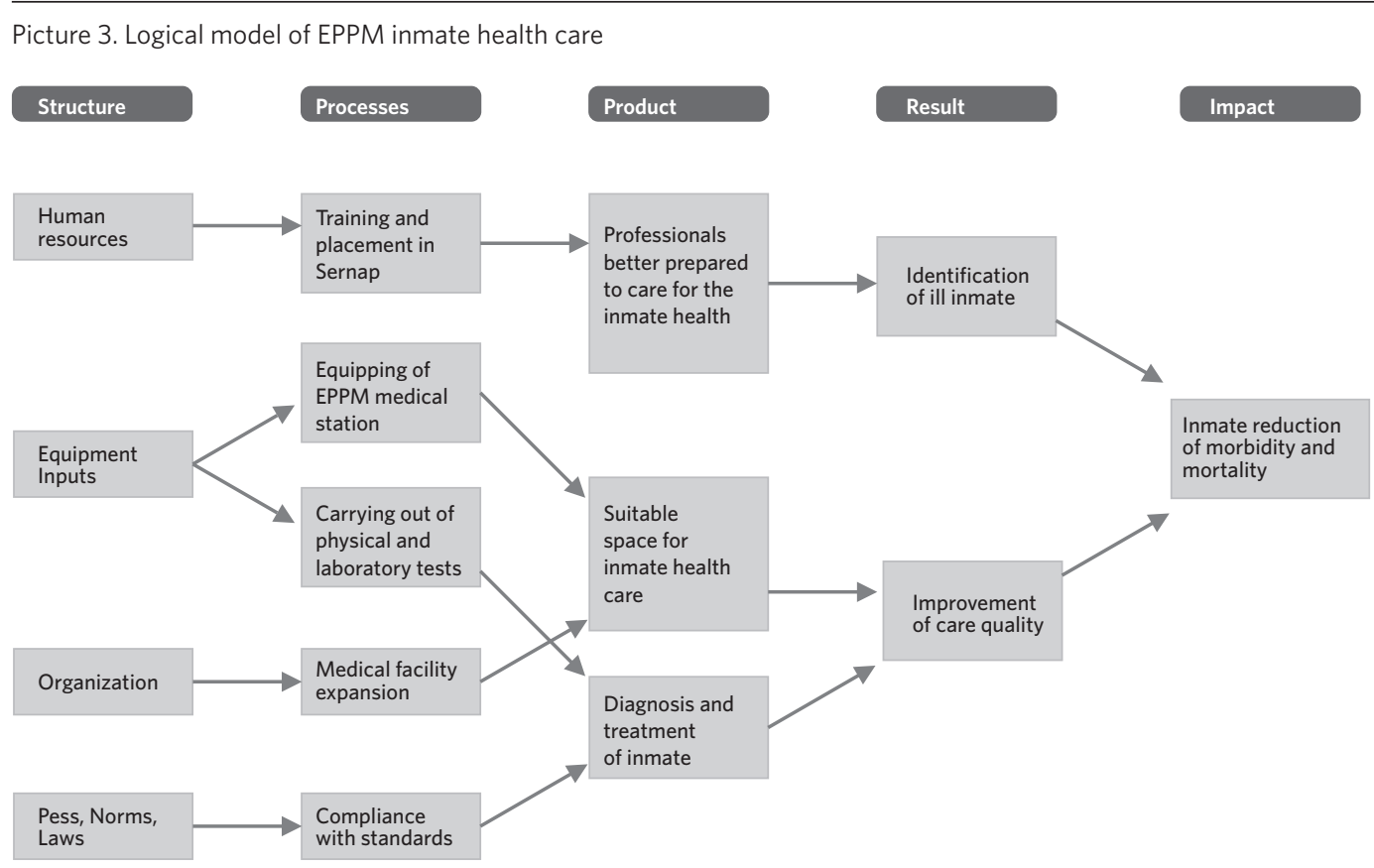

Source: Prepared by the authors.

Pess - Strategic Plan of the Health Sector.

\section{EPPM Political-organizational context}

Regarding the organizational structure, EPPM receives the SNS support as for medical care and complementary diagnostic tests in the hospital units, medicines, TB screening programs and HIV testing due to a memorandum of understanding signed between the Ministries of Justice and Health. Two poles of power can be identified herein: on one side, the correction facility management is responsible for the inmate guardianship, ensuring his/ her conditions of rehabilitation and social reintegration, and, on the other side, the SNS provides the services, programs, technological equipment and knowledge for the necessary care to ensure the inmate attention in an adequate way.

In addition, the correctional facility signed partnership contracts with some religious so to provide psychosocial and spiritual support, and assist the inmate rehabilitation. Similarly, some non-governmental organizations support the activities of sanitation, construction of restrooms and training of peer educators. 
Therefore, given the health importance, particularly due to the characteristics of a correctional facility, respondents were asked about which strategic actions can be adopted to improve care.

[...] Taking health as fundamental right established in the constitution of the Republic, inmates have the right to health and should benefit from all public health interventions, because after seclusion they return to the community and may run the risk of transmitting diseases or becoming infected if they do not adopt prevention measures. (IC5).

The health of persons deprived of liberty is undoubtedly a matter of public health. Minayo and Constantino 4 remember that the coexistence of inmates with their families, facility agents and staff can spread diseases if health conditions are precarious.

When asked what improvements could be carried out so to ensure good assistance to inmates, the interviewees mentioned administrative and structural issues. As for human resources, they mentioned the training of health staff and, as for material ones, they referred the acquisition of appropriate health equipment for the inmate health assistance:

[...] Construction of a correctional facility health center and its outfit. Hiring of nursing physicians, pharmacists and administrative agents. (IC3).

In his response, IC2 refers to one of the fundamental principles of the Republic Constitution, which is the right to life and health, regardless the individual situation. However, correctional facilities do not contribute to the provision of humanizing standards, becoming an increasingly harsh reality for health teams that work every day to contribute to improving the inmate health ${ }^{\mathbf{2 4}}$.

[...]Training middle and higher level health staff, improve the correctional facility infrastructure to reduce confinement, improve health facility to improve the inmate care flowchart, acquisition of medical supplies and hospital equipment, and provide greater involvement of Misau. Broadermind of the correctional facility managers in the discussion and adoption of health packages offered to the general inmate population. (IC2).

PM1 respondent also advocates the need to improve the structural conditions of the prison health service:

[...] To improve infrastructure, enlarge cabins, laboratory, ATS, ensure current drinking water, increase the number of professionals, hire a dermatologist, psychiatrist, ophthalmologist etc. Surgery, stomatology and physiotherapy. (PM1).

Suggestions of administrative nature were reduced to lack of human resources and need for training and allocation of added staff from other areas of expertise so to create conditions to ensure a 24-hour service. Although Kölling et al. ${ }^{5}$ consider that the increase in specialized professionals in a given unit does not imply health care improvement, since there are other factors indispensable to improving quality of life and health care, Damas ${ }^{25}$ and other authors ${ }^{18}$ see the existence of a multidisciplinary health team as vital to reduce the demand for other health units.

Suggestions of structural nature concern the size of the medical station, type of services to be provided, and lack of material resources. Regarding the medical station dimensions, the reference was addressed to its reduced size and absence of several useful cabins to propitiate a good functionality. The lack of physical space, the lack of equipment and other materials related to insufficient human resources are factors that impact and hinder in some way a good provision of health care to inmates, as stated by two respondents:

[...] Given the specificity of the inmate population, I suggest organizing a health service that includes 
promotion, preventive, curative and rehabilitative actions, particularly for the main correctional facilities, carrying out human resources, materials, finance and infrastructure. (IC5).

[...] Assignment of a share from Sernap's budget for health care, construction of inmate hospital unit in each region providing hospitalization. Training of schooled inmates in health disciplines. Creation of a monitoring system. (IC2).

Such suggestions indicate that there is not any health service that ensures complete attention to the inmate health. That lack of material and financial resources as of professionals generate precariousness in care. Results show that the inmate care is not fully ensured by the correctional system, much less by SNS.

The lack of knowledge by health professionals about the memorandum signed between the Ministries of Justice and Health, together with the lack of clear policy on the inmate health, does not release the duty to care for that group already excluded for its social condition. The lack of connection between Sernap and Misau causes the inmate attention or health care to be inadequate and insufficient. Health is a right of every citizen consecrated in CRM and duty of the State to provide it to all without discrimination. There is a concern that also the inmate enjoys what is constitutionally consecrated as the disease transmission to the community be prevented, confirming what Diuana et al..$^{10}$ stated in their study.

Activities related to health promotion and disease prevention need to be further intensified due to the facility overcrowding and to the inmates who arrive carrying of suspicion of communicable diseases. The literature reveals that those diseases are frequent in that environment ${ }^{5}$. As for the Mozambique report, TB, ITs, HIV and Aids are diseases that affect the Mozambican inmate population ${ }^{3}$.

The results of the study indicate that the current assistance model does not fully meet the inmate health problems and assistance needs. So, provided a clear view of the norms, structure and processes of a correctional center health care, to carry out an evaluation seems pertinent and feasible.

The main limitations of this research involved the insufficiency or lack of information issued in Misau reports regarding inmate attention, as well as the absence of studies on inmate health care in Mozambique. Also, the self-answering questionnaire did not allow further deepening of the questions. Despite the carrying out of the investigation on a service for whose provision the researcher has responsibilities, it is noteworthy that this study was only attainable because of the access to the correctional system and to careful data collection.

\section{Final remarks}

This evaluability study aimed to aggregate different perspectives by means of different sources of information, thus obtaining the evidence or contradictions among findings, allowing to verify that inmate health care is a subject that lacks debate and is not properly addressed in SNS health policies. Although the inmate population is treated in the EPs surrounding hospitals, Misau reports do not contain any reference, information or approach to that population.

The case study brought elements adding to the design of a future evaluation of the inmate health care in Maputo or even in Mozambique. Many were the findings revealing the need for adjustments and adequacy of also the structure and processes of the inmate health care as the involvement of key actors or the prioritization in the country health policy agenda. However, efforts are to be made so to monitor and evaluate the quality of existing actions and to induce the implementation of new actions.

So that inmates live together in a healthy environment, some competences must be shared, bearing in mind that the general infrastructure matter, including the construction of health facilities, is within the responsibility of the 
Ministry of Justice. Nevertheless, SNS has the obligation for outfitting and allocating human resources to ensure attention as stated in the memorandum.

The lack of an updated national health policy in Mozambique that includes prison health does not allow for a clear guidance on the procedures and actions to be developed in the correctional facility as to the promotion, prevention and medical assistance of inmates. PE overcrowding problem, associated to inadequate health care, creates conditions for the emergence of several infectious diseases and for the overlap increase of individual, social and programmatic vulnerability.

The outsourcing or delegation of health professional activities, especially those of promotion, assigning those activities to peer educators or to the 'health chief', empowers those people within the correctional facility and yields 'comfort' not only for health personnel but also for officers.

Given the importance of the inmate health care and the conclusion that the evaluation is feasible, we believe that future studies will be carried out as from the critical points raised in this study.

In that case, we recommend: the wording of informational materials in all the languages of the Country and for different cultural groups so to facilitate their understanding by the inmates, and that the informational material be simple and written in clear and accessible language; the increase in the number of professionals to ensure 24-hour care and timely medication; supervision and regular technical support by the SNS to address difficulties in medical material and drug management; rehabilitation and expansion of the health facility in order to improve the provision of care; the allocation of an ambulance-type vehicle for the immediately transfer of patients to extramural health units; the building of an information system on EPPM health actions and outcomes; and the updating of the national health policy, which should include the correctional facility health.

In general terms, SNS needs to take on the responsibility of health caregiver of all Mozambican citizens, inmates included. The Ministries of Health and of Justice and the Constitutional and Religious Affairs should join efforts as a way to create and harmonize policies that promote and improve health in the correctional system. Acting in a more integrated perspective can contribute to the construction of a correctional health system closer relied on human rights and on more equitable access to health in the Correctional Facilities of Mozambique, as well as in other countries.

\section{Collaborators}

Anli C (0000-0003-3457-3707)* worked on the project design, on data collection, analysis and interpretation, on the content review, and on the paper wording. Cruz MM (0000-00024061-474X)* worked on the project design, on data interpretation, on the content review, and on the paper final approval. Oliveira LD (0000-0002-8208-4134)* worked on the project design, on the content review, and on the paper final approval. 


\section{References}

1. Le Marcis F. A impossível governança da saúde em prisão? Reflexões a partir da MACA (Costa do Marfim). Ciênc. Saúde Colet. 2016; 21(7):2011-20.

2. Walmsley R. World prison population list. [internet]. 2018 [acesso em 2020 ago 22]. Disponível em: http:// www.Prisionstudies.org/sites/default/files/resources/downloads/wppl.12.pdf.

3. Moçambique. Serviço Nacional Penitenciário. Relatório anual. Maputo: Ministério do Interior; 2019.

4. Minayo MCS, Constantino R. Deserdados sociais: condições de vida e saúde dos presos do Estado do Rio de Janeiro. Rio de Janeiro: Editora FHC; 2016.

5. Kölling GJ, Silva MBB, Sá MCD. O Direito à Saúde no Sistema Prisional. Temp - Act de Saúde Coletiva. 2013; 7(1)281-97.

6. Moçambique. Constituição, 2004. Constituição da República de Moçambique. Maputo: Assembleia da República; 2004.

7. Jólluskin G, Castro-Rodrigues A, Silva I, et al. Saúde e reclusão: de uma breve contextualização do fenómeno ao papel dos profissionais de saúde. Rev sociologia. 2014; (13):89-102.

8. Moçambique. Serviço Nacional Penitenciário. Relatório anual. Maputo: Ministério da Justiça; 2017.

9. Organização das Nações Unidas. Regras de Mandela: Regras Mínimas das Nações Unidas Para o Tratamento de Presos. Brasília, DF: ONU; 2016.

10. Diuana V, Lhuilier D, Sánchez AR, et al. Saúde em prisões: representações e práticas dos agentes de segurança penitenciária no Rio de Janeiro, Brasil. Cad. Saúde Pública. 2008; 24(8):1887-1896.

11. Bezerra LCA, Cinthia KAA, Yluska ACR, et al. Identificação e caracterização dos elementos constituintes de uma intervenção: pré-avaliação da política ParticipaSUS. Ciênc. Saúde Colet. 2012; 17(4):883-900.
12. Thurston WE, Potvin L. Evaluability Assessment: A Tool for Incorporating Evaluation in Social Change Programmes. Evaluation. 2003; 9(4):453-69.

13. Thurston WE, Ramaliu A. Evaluability assessment of survivors of torture program: lessons learned. Can J Program Eval. 2005; 20:1-25.

14. Silva RN, Guarda FRB, Hallal PC, et al. Avaliabilidade do Programa Academia da Saúde no Município do Recife, Pernambuco, Brasil. Cad. Saúde Pública. 2017; 33(4):e00159415.

15. Miranda WD, Guimarães EAA, Campos DS, et al. Programa Nacional de Suplementação de Vitamina A no Brasil: um estudo de avaliabilidade. Rev Panam Salud Publica. 2018; (42):e182.

16. Oliveira LGD. Avaliação da implantação do Programa de Controle da Tuberculose em unidades prisionais de dois estados brasileiros [tese]. Rio de Janeiro: Escola Nacional de Saúde Pública Sergio Arouca; 2014.

17. Bardin L. Análise de Conteúdo. São Paulo: Edições $70 ; 2016$.

18. Oliveira LGD, Natal S, Camacho LAB. Análise da implantação do Programa de Controle da Tuberculose em unidades prisionais no Brasil. Cad. Saúde Pública. 2015 ; 31(3):543-554.

19. Arroyo JM, Astier P. Calidad asistencial en Sanidad Penitenciaria. Análisis para un modelo de evaluación. Rev Esp Sanid Penit. 2003; (5):60-76.

20. Coyle A. Administração Penitenciaria: Uma abordagem de Direitos Humanos. Londres: International Centre for prision studies; 2002.

21. Minayo MCS, Ribeiro AP. Condições de saúde dos presos do estado do Rio de Janeiro, Brasil. Ciênc. Saúde Colet. 2016; 21(7): 2031-2040.

22. Sánchez A, Larouzé B. Controle da tuberculose nas 
prisões, da pesquisa à ação: a experiência do Rio de Janeiro, Brasil. Ciênc. Saúde Colet. 2016; 21(7):20712079.

23. Martins JCB. A prática da saúde em ambiente Prisional: Relação entre Profissionais de Saúde e Reclusos [monografia]. Porto: Faculdade de Ciências Humanas e Sociais, Universidade Fernando Pessoa; 2013.

24. Garrido Cardoso HHG. A Saúde dos detentos no sistema penitenciário brasileiro: Uma análise de um Instituto Penal do Estado do Rio de Janeiro. [disser- tação]. Porto: Faculdade de Ciências Humanas e Sociais, Universidade Fernando Pessoa; 2019.

25. Damas FB. Assistência e Condições de Saúde nas Prisões de Santa Catarina, Brasil. Rev. Saúde Públ. 2012; 5(3):6-22.

Received on $12 / 26 / 2019$

Approved on 08/28/2020

Conflict of interest: non-existent

Financial support: non-existent 